
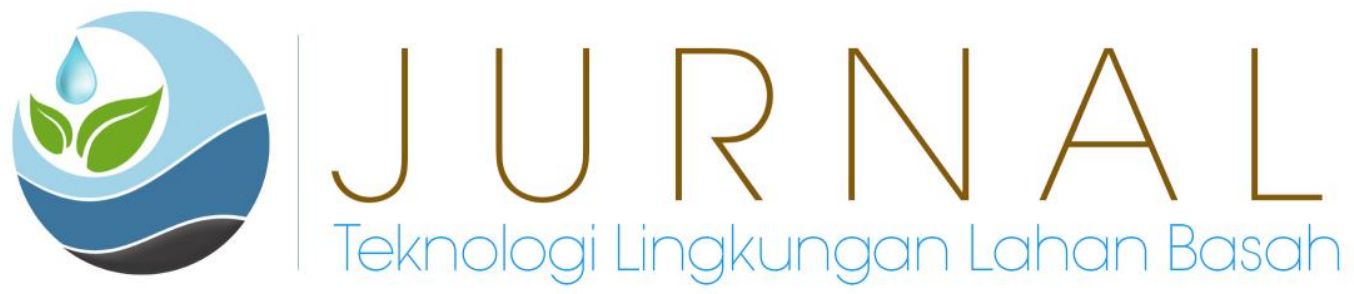

\title{
Coco Fiber Sebagai Filter Limbah Cair Rumah Makan Cepat Saji
}

\author{
Kiki P. Utomo ${ }^{1}$, Suci Pramadita ${ }^{1}$, dan Ochih saziati ${ }^{1}$ \\ ${ }^{1}$ Jurusan Teknik Lingkungan Universitas Tanjungpura \\ E-mail : kiki.p.utomo@gmail.com
}

\begin{abstract}
The development of fast food restaurant business in Pontianak City has an impact on the increasing quantity of waste water that potentially cause water pollution if disposed directly to water body without processing it first. This study aims to process waste water from fast food restaurant using coco fiber-based filtration method so that it can improve the quality of waste water in terms of $\mathrm{pH}$, BOD and TSS parameters. Coco fiber is characterized using SEM and FTIR methods. The research was conducted by making prototype of laboratory scale wastewater treatment unit with 2 filters namely coco fiber and active charcoal-sand-coco fiber-gravel combination. The test is done by conducted pre-test and post-test in which parameters are measured before and after processing to observe the effectiveness of filtration method. The results showed that $\mathrm{pH}$ of waste water increased from 6.1 to 6.4 after passing filtration unit using coco fiber-based filtration and to 7.8 for active-sand-coco fiber-gravel combination filtration. Processing waste water using coco fiberbased filtration system resulted in $98.58 \%$ BOD reduction and TSS $83.51 \%$. While processing of waste water using combination of activated charcoal-sand-coco fiber-gravel filtration resulted in a reduction of BOD $78.33 \%$ and TSS $81.19 \%$.
\end{abstract}

Keywords: coco fiber; filtration; waste water; fast food restaurant

\begin{abstract}
Abstrak
Perkembangan usaha rumah makan cepat saji di Kota Pontianak berdampak pada menurunnya kualitas perairan. Penyebabnya adalah pembuangan limbah cair ke badan air tanpa pengolahan terlebih dahulu. Penelitian ini bertujuan untuk mengolah limbah cair rumah makan cepat saji menggunakan metode filtrasi berbahan dasar coco fiber. Coco fiber dikarakterisasi menggunakan metode SEM dan FTIR. Spektra FTIR coco fiber menunjukkan puncak serapan pada bilangan gelombang 3159-3576 $\mathrm{cm}^{-1}$ yang dimiliki oleh gugus fungsi-OH. Dua puncak yang juga menonjol di daerah bilangan gelombang 2800-2924 $\mathrm{cm}^{-1}$ diduga adalah regang $\mathrm{C}-\mathrm{H}$ alifatik dari kelompok metil dan metilen dari lignin serbuk coco fiber. Penelitian dilakukan dengan membuat purwarupa alat pengolah limbah cair berskala laboratorium dengan 2 unit filter yaitu coco fiber dan kombinasi arang aktif-pasir-coco fiber-kerikil. Pengujian dilakukan dengan metode pre-test dan post-test yaitu pengukuran parameter seperti pH, BOD dan TSS sebelum dan sesudah pengolahan untuk mengetahui efektivitas pengolahan. Hasil penelitian menunjukkan bahwa limbah cair setelah melalui unit filtrasi mengalami peningkatan pH dari 6,1 menjadi 6,4 untuk sistem coco fiber dan 7,8 untuk sistem kombinasi arang aktif-pasir-coco fiber-kerikil. Filtrasi menggunakan sistem coco fiber menghasilkan pengurangan BOD 98,58\% dan TSS 83,51\%. Sedangkan filtrasi menggunakan sistem kombinasi arang aktif-pasir-coco fiber-kerikil menghasilkan pengurangan BOD 78,33\% dan TSS 81,19\%.
\end{abstract}

Kata Kunci: coco fiber; filtrasi; limbah cair; rumah makan cepat saji 

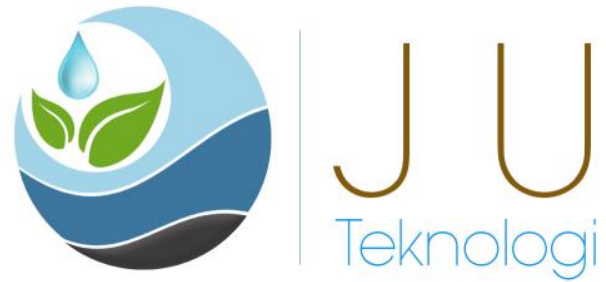

\section{PENDAHULUAN}

Usaha rumah makan cepat saji di Kota Pontianak berkembang pesat seiring meningkatnya permintaan masyarakat akan jasa boga yang cepat, praktis dan variatif. Perkembangan ini berdampak pada meningkatnya kuantitas air limbah dari usaha rumah makan yang berpotensi menyebabkan permasalahan lingkungan bila tidak ditangani dengan seksama. Menurut Permen LH RI No. 5 Tahun 2014 tentang Baku Mutu Air Limbah, limbah rumah makan tergolong ke dalam limbah cair domestik. Saat ini limbah domestik menjadi pencemar paling dominan di badan air Kota Pontianak dengan presentasinya mencapai $60-70 \%$. Bahan pencemar utama dalam limbah domestik adalah bahan organik, padatan dalam bentuk tersuspensi (TSS), minyak dan lemak yang apabila dibuang langsung ke badan air akan mengakibatkan pencemaran (Filliazati, Apriani, \& Zahara, 2013).

Sumber utama air limbah rumah makan berasal dari pencucian bahan makanan, pencucian peralatan memasak dan peralatan makan, air pembersih lantai dan sisa bahan makanan dan sajian olahan makanan. Pada umumnya minyak dan lemak dapat teratasi menggunakan grease trap atau flotasi sehingga tidak menjadi masalah yang berat. Sedangkan air sisa pencucian peralatan memasak dan peralatan makan umumnya mengandung bahan organik yang dapat membusuk atau terdegradasi oleh aktivitas mikroorganisme dan bila dibuang ke badan air akan meningkatkan kadar TSS dan kebutuhan oksigen biologi (BOD) (Andiese, 2011).

Pengolahan limbah cair domestik umumnya menggunakan metode biologi yang memanfaatkan mikroorganisme pengurai sebagai pendegradasi bahan pencemar organik.

Rumah makan cepat saji umumnya menggunakan bahan kimia yang bersifat asam, antiseptik dan disinfektan untuk pencucian peralatan makanan dan pembersih lantai. Bahan kimia yang bersifat asam dapat menyebabkan $\mathrm{pH}$ limbah menjadi rendah $(\mathrm{pH}<7)$ dan tidak aman untuk lingkungan. Antiseptik merupakan zat yang digunakan untuk menghambat pertumbuhan atau membunuh bakteri. Disinfektan adalah bahan kimia yang dapat mematikan sel vegetatif bakteri tetapi belum tentu mematikan sporanya (Isadiartuti \& Sari, 2005).

Berdasarkan sifat tersebut maka keberadaan bahan-bahan antiseptik dan disinfektan di dalam air limbah bersifat tidak menguntungkan dalam pengolahan limbah karena dapat menghambat kinerja mikroorganisme dalam menurunkan kadar bahan pencemar organik. Sehingga IPAL dengan sistem biologis tidak efektif untuk pengolahan limbah cair rumah makan cepat saji. Terkecuali jika pengolahan bahan pencemar organik dilakukan secara terpisah. Namun pemilik rumah makan cepat saji menganggap pengolahan terpisah tidak efisien karena memerlukan lahan yang lebih besar. Sedangkan lahan yang tersedia terbatas dan lebih diutamakan untuk menampung pengunjung rumah makan. Selain itu pengolahan terpisah juga dianggap lebih mahal karena harus membuat dan mengoperasikan dua buah IPAL.

Berdasarkan permasalahan yang telah diuraikan, perlu dikembangkan metode pengolahan limbah cair yang lebih efektif untuk rumah makan cepat saji. Metode 

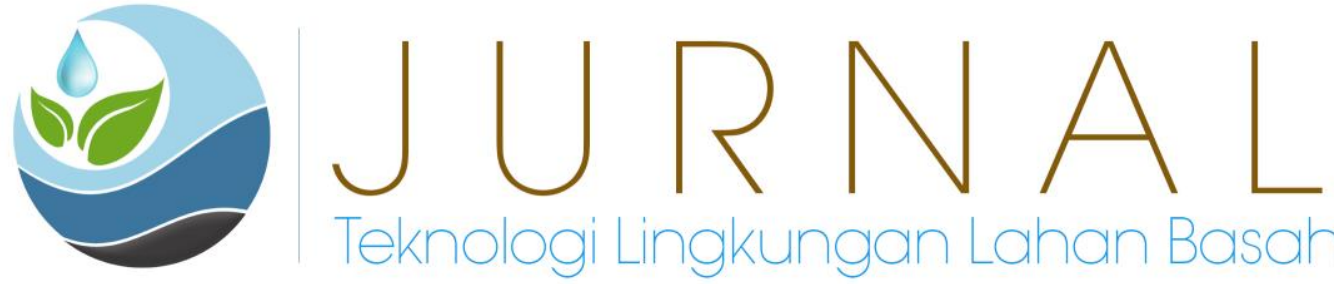

yang diinginkan harus dapat menurunkan konsentrasi bahan organik, padatan tersuspensi, minyak dan lemak dengan kondisi air limbah tercampur bahan kimia yang bersifat asam, antiseptik dan disinfektan. Selain itu metode pengolahan yang diinginkan juga harus sederhana, murah dan mudah baik pembuatan maupun pengoperasiannya.

Salah satu metode sederhana yang berpotensi untuk dikembangkan adalah dengan penyaringan menggunakan media filter dari serat alam. Serat alam lebih dipilih dibanding serat buatan karena memiliki beberapa kelebihan seperti: kaku, murah, ringan, tidak beracun, tersedia dalam jumlah yang banyak dan ramah lingkungan (Diharjo, 2006) (Joseph, Thomas, \& Pavithran, 1995). Salah satu jenis tanaman yang menghasilkan serat alam adalah kelapa (Cocos nucifera). Hal yang menjadi pertimbangan penggunaan serat kelapa (coco fiber) adalah serat ini mudah diperoleh di alam, serta serat ini juga memiliki sifat-sifat yang menguntungkan untuk menyaring material dalam air limbah. Penggunaan serat kelapa untuk media filter pengolahan air khususnya air limbah belum pernah dilakukan.

Kinerja coco fiber dalam menyaring bahan pencemar dapat dimaksimalkan bila dikombinasikan dengan bahan lain sebagai filter misalnya karbon aktif, pasir dan kerikil. Karbon aktif dapat menurunkan kadar TSS limbah pencucian umbi dengan tingkat efektivitas sebesar 93,93\% (Sihombing, 2007). Penelitian lain yang membandingkan hasil pengolahan limbah cair batik menggunakan karbon aktif, pasir aktif dan kombinasi karbon aktif dan pasir aktif dengan ketinggian tumpukan $80 \mathrm{~cm}$ dan waktu tinggal 75 menit dalam menurunkan kadar BOD dan TSS, menunjukkan tingkat efisiensi karbon aktif dalam penurunan kadar BOD dan TSS berturut-turut $82,3 \%$ dan $86,5 \%$. Tingkat efisiensi pasir aktif dalam penurunan kadar BOD dan TSS adalah 53,3\% dan 77,2\%.

Kesimpulannya adalah kedua media adsorben tersebut (karbon aktif dan pasir aktif) lebih baik dikombinasikan untuk pengolahan limbah batik dengan efisiensi penurunan terhadap BOD dan TSS sebesar $\pm 69 \%$ dan $\pm 79 \%$ (Sumarni, 2012).

Penggunaan kerikil sebagai media biofilter dalam mengolah air limbah rumah makan dengan waktu tinggal 8 jam memiliki efisiensi penyisihan parameter BOD dan TSS mencapai 94,83\% dan 95\% (Zahra \& Purwanti, 2015). Melihat besarnya kemampuan bahan-bahan tersebut menurunkan konsentrasi bahan pencemar memberikan peluang untuk dikombinasikan dan diaplikasikan lebih lanjut bersama coco fiber dalam pengolahan air limbah rumah makan cepat saji.

Penelitian penggunaan coco fiber dalam pengolahan limbah cair akan mendukung upaya Pemerintah Kota Pontianak mewajibkan setiap rumah makan untuk memiliki instalasi pengolahan air limbah (IPAL) sesuai dengan amanat Perda Kota Pontianak No. 5 Tahun 2013 tentang Pengelolaan Kualitas Air dan Pengendalian Pencemaran Air. Hasil penelitian ini juga akan memberikan informasi tentang alternatif teknologi yang mampu mengurangi bahan pencemar di dalam air limbah rumah makan sehingga memenuhi baku mutu dan aman dibuang ke lingkungan. 

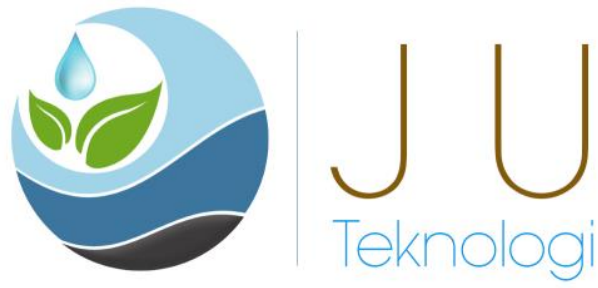

\section{METODE PENELITIAN}

Penelitian akan dilakukan di workshop Program Studi Teknik Lingkungan Fakultas Teknik Universitas Tanjungpura Pontianak. Pengujian SEM dan FTIR dilakukan di LPPT UGM Yogyakarta. Pengujian sampel air limbah dilakukan di Laboratorium Sucofindo Pontianak.

Peralatan yang digunakan pada penelitian ini adalah drum $60 \mathrm{~L}$ (diameter $40 \mathrm{~cm}$, tinggi $53 \mathrm{~cm}$ ), stop kran 1 inci, drat pipa luar dalam, L-bow 1 inci, shower 1 inci, lem pipa, isolatif pipa, meteran, spidol permanen, bor listrik, winkler $300 \mathrm{ml}$, botol plastik $600 \mathrm{ml}$, ayakan 16 mesh dan 200 mesh, neraca analitik, oven, $\mathrm{pH}$ meter, SEM (tipe JEOL JSM-6510LA dengan perbesaran 10-300.000 x dan resolusi 1-10 nm) dan FTIR (rentang spektra 485-8500 cm-1; resolusi $>0,7 \mathrm{~cm}-1$; short term stability $0,09 \%)$.

Bahan yang disiapkan untuk unit filter dan analisis laboratorium adalah coco fiber, karbon aktif, pasir, kerikil dan sampel air limbah. Peubah yang diukur dalam penelitian ini adalah nilai parameter $\mathrm{pH}, \mathrm{BOD}$ dan TSS yang terdapat dalam limbah cair rumah makan cepat saji sebelum dan setelah melewati pengolahan.

Uji pendahuluan meliputi karakterisasi limbah cair rumah makan cepat saji sebelum pengolahan dari segi parameter $\mathrm{pH}, \mathrm{BOD}$ dan TSS (sampel diambil dari outlet limbah). Kemudian dilanjutkan karakterisasi coco fiber menggunakan SEM dan FTIR. Karakterisasi bertujuan untuk melihat pengaruh pengolahan coco fiber dengan cara basah yaitu
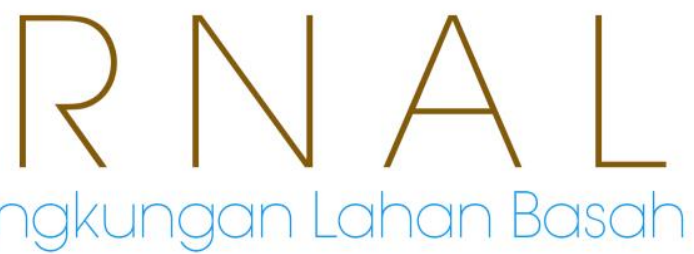

perendaman selama 5 hari lalu dikeringkan sebelum dilakukan pemisahan untuk memperoleh coco fiber.

Bak pengumpul awal merupakan tampungan limbah cair dengan volume 50 L yang berasal dari sisa kegiatan rumah makan cepat saji (pencucian peralatan makanan, sisa makanan, air cucian pembersih lantai). Setelah ditampung di dalam bak pengumpul awal, limbah cair akan dilewatkan ke 2 unit filtrasi yaitu unit filter I yang hanya terdiri dari coco fiber dan unit filter II dengan susunan karbon aktif-pasir-coco fiber-kerikil. Dua unit filtrasi bertujuan untuk melihat perbandingan efektivitas antara coco fiber dan kombinasi karbon aktif- pasir-coco fiber-kerikil dalam menurunkan kadar TSS dan BOD. Pasir yang digunakan adalah pasir yang lolos pada ayakan 16 mesh. Semua bahan filter yang digunakan melalui proses pretreatment yaitu pencucian sebanyak $3 x$ menggunakan air hujan lalu dikeringkan. Khusus untuk karbon aktif dan pasir diaktivasi secara fisik menggunakan pemanasan pada suhu $105^{\circ} \mathrm{C}$.

Setelah melewati filtrasi, limbah cair ditampung di bak pengumpul akhir. Pada bak ini dilakukan sampling air limbah hasil pengolahan kemudian diuji terhadap parameter $\mathrm{pH}$, BOD dan TSS sehingga diketahui efektivitas pengolahan limbah cair rumah makan cepat saji yang dirancang.

\section{HASIL DAN PEMBAHASAN}

Karakterisasi SEM Coco Fiber. Pengamatan melalui SEM dilakukan untuk melihat kondisi permukaan 

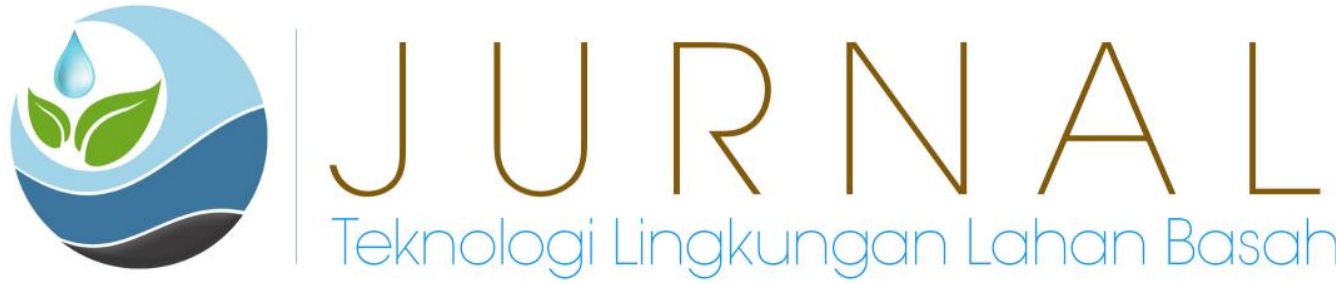

(morfologi) coco fiber. Pengamatan morfologi coco fiber melalui SEM dilakukan dengan perbesaran 300x dan 1000x. Hasil foto SEM coco fiber hasil penelitian disajikan pada Gambar 1.

Hasil uji morfologi pada Gambar 1a dan $1 b$ menunjukkan bahwa perlakuan perendaman dengan air biasa tidak merubah morfologi permukaan dari coco fiber.
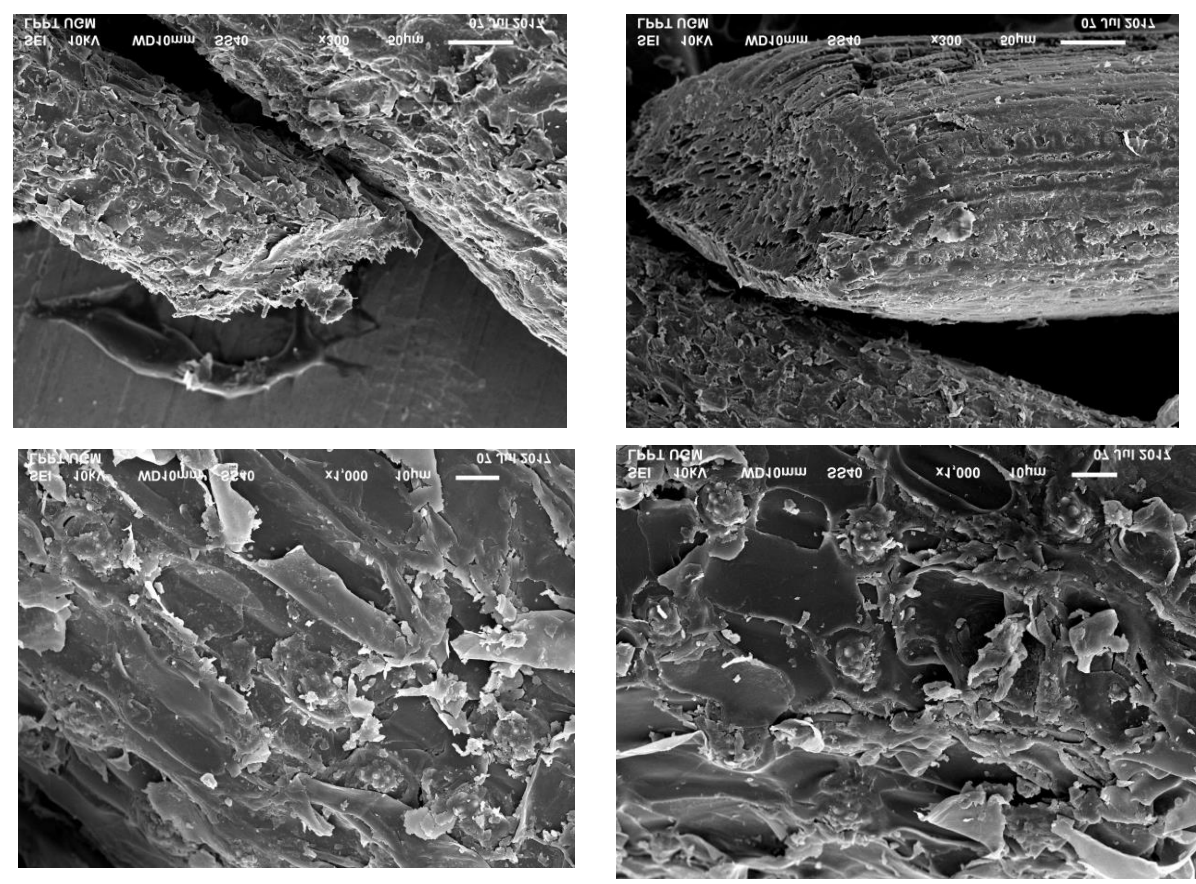

(a) Metode Basah

(b) Metode Kering

Gambar 1. Hasil Uji SEM Coco Fiber

Karakterisasi FTIR Coco Fiber. dan metode kering relatif sama seperti Spektrum FTIR coco fiber hasil yang tersaji pada Gambar 2. pengolahan menggunakan metode basah

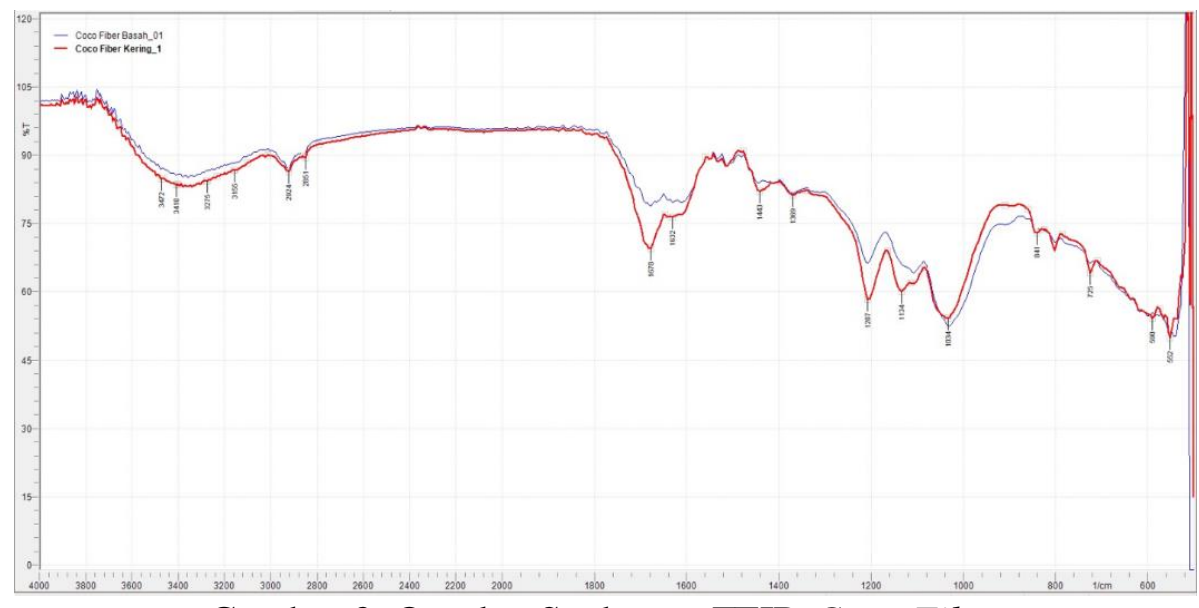

Gambar 2. Overlay Spektrum FTIR Coco Fiber 

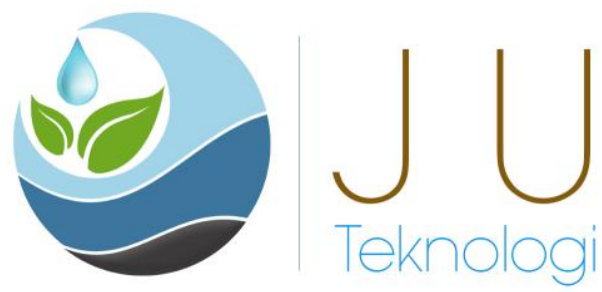

Pada Gambar 2 untuk semua spektra FTIR coco fiber hasil penelitian terlihat puncak serapan pada bilangan gelombang 3159-3576 $\mathrm{cm}^{-1}$. Puncak dengan bentuk yang melebar menunjukkan ciri khas adanya ikatan intermolekular dan hidrogen bebas yang dimiliki oleh gugus fungsi $-\mathrm{OH}$ stretching vibrasi dari serbuk coco fiber.

Ada 2 puncak yang juga menonjol di daerah bilangan gelombang 2800-2924 $\mathrm{cm}^{-1}$ yang diduga adalah regang $\mathrm{C}-\mathrm{H}$ alifatik dari kelompok metil dan metilen dari lignin serbuk coco fiber. Hasil pengujian FTIR menunjukkan bahwa perlakuan perendaman coco fiber dengan air tidak mengurangi kadar lignin dalam coco fiber.

\section{Rancangan Alat Pengolahan Limbah Cair Rumah Makan Cepat Saji.}

Pengolahan air limbah dirancang dengan menerapkan proses filtrasi dengan 2 perlakuan yang berbeda. Unit filter pertama berbahan dasar coco fiber sedangkan unit filter kedua disusun

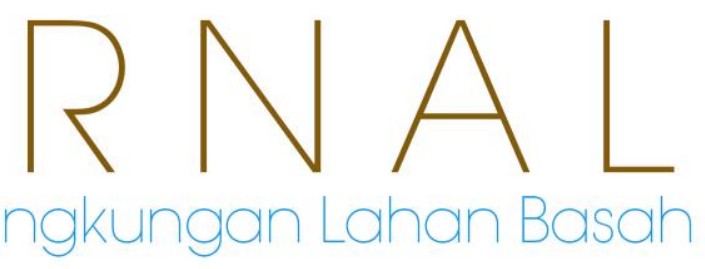

secara vertikal dari bawah keatas yaitu kerikil $20 \mathrm{~cm}$, coco fiber $10 \mathrm{~cm}$, pasir 5 $\mathrm{cm}$ dan karbon aktif $5 \mathrm{~cm}$. Media filter seperti karbon aktif dan kerikil berfungsi untuk menurunkan warna, bau, rasa, dan zat-zat yang masih tersisa di dalam air pengolahan.

Karbon aktif terbuat dari batok atau tempurung kelapa yang dibakar sampai menjadi karbon. Karbon aktif berfungsi sebagai penyerap bau, menghilangkan warna kuning dan unsur yang merugikan di dalam kandungan air. Pembuatan karbon ini tanpa pencampuran kimia tertentu sehingga aman digunakan untuk keperluan pemfilteran. Karbon aktif atau active carbon memiliki daya serap yang tinggi dan mudah menjernihkan air (Kusnaedi, 2010). Coco fiber sendiri berfungsi untuk menyisihkan material tersuspensi dan senyawa organik sehingga TSS dan BOD dapat diturunkan. Fungsi lain dari kerikil yaitu untuk menahan material filter di atasnya agar tidak terbawa saat penyaringan. 

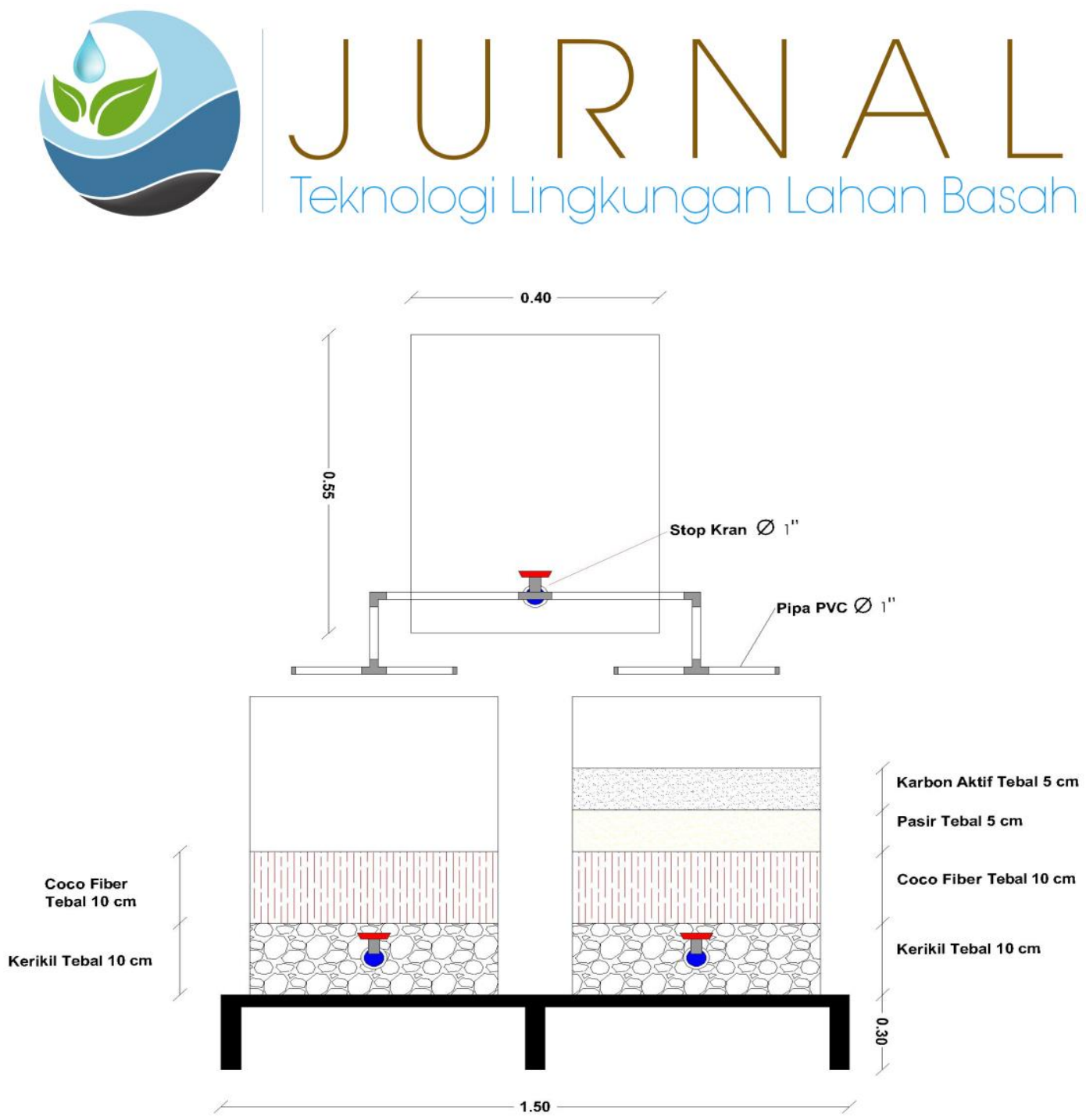

TAMPAK DEPAN

Gambar 3. Desain Alat Pengolahan Limbah Rumah Makan Cepat Saji

Kualitas Limbah Hasil Pengolahan.

Sampel penelitian adalah air limbah yang diambil dari salah satu rumah makan cepat saji di Kota Pontianak dan limbah yang diambil adalah limbah yang belum melalui proses pengolahan (inlet).

Jumlah sampel yang diambil sebanyak 2 sampel yaitu untuk keperluan pengujian limbah cair sebelum pengolahan (pre test) dan sesudah pengolahan (post test). Saat pengambilan sampel juga dilakukan penurunan derajat warna, dan konsentrasi bakteri yang cukup tinggi, serta penurunan kandungan zat organik. pengukuran parameter $\mathrm{pH}$ secara in situ menggunakan metode potensiometrik.

Metode filtrasi yang dilakukan dalam penelitian ini merupakan salah satu proses pengolahan limbah cair yang efektif, murah dan sederhana. Proses filtrasi dikatakan efektif, karena dapat membantu proses pemisahan atau pengurangan kekeruhan air limbah sampai pada tingkat yang dapat ditoleransi (sesuai baku mutu),

Proses ini bersifat ekonomis (murah) karena pada dasarnya proses pengolahannya tidak memerlukan energi dan bahan kimia, serta pembuatan alatnya tidak memerlukan biaya besar. 

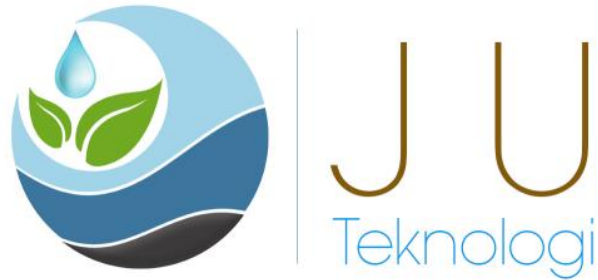

Proses pengolahan bersifat sederhana karena pengoperasiannya tidak memerlukan tenaga dengan Pendidikan atau keterampilan khusus.

Tabel 1. menunjukkan efektivitas media filtrasi yang ditentukan berdasarkan
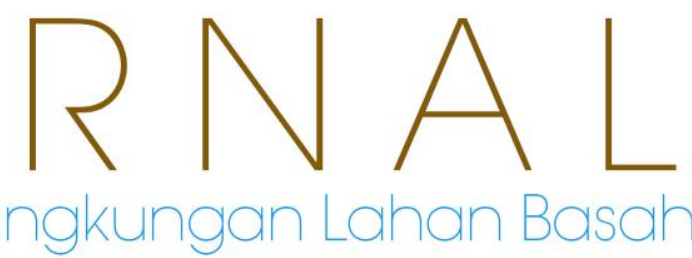

hasil pengujian terhadap parameter $\mathrm{pH}$, BOD dan TSS limbah cair sebelum dan setelah melalui proses pengolahan dengan menggunakan 2 metode sistem filtrasi yang berbeda yaitu sistem coco fiber dan sistem karbon aktif-pasir-coco fiber-kerikil.

Tabel 1. Efektivitas Media Filtrasi yang Ditentukan oleh Parameter uji

\begin{tabular}{lcccc}
\hline Parameter & $\begin{array}{c}\text { Sebelum } \\
\text { Pengolahan }\end{array}$ & \multicolumn{2}{c}{ Setelah Pengolahan } & Baku \\
\cline { 3 - 4 } & $\begin{array}{c}\text { Coco } \\
\text { Fiber }\end{array}$ & Kombinasi & mutu* \\
\hline $\mathrm{pH}$ & 6,1 & 6,4 & 7,8 & $6-9$ \\
$\mathrm{BOD}$ & 1010.73 & 14,36 & 218,99 & 100 \\
$(\mathrm{mg} / \mathrm{L})$ & & & & \\
$\mathrm{TSS}$ & 776,00 & 128,00 & 146,00 & 100 \\
$(\mathrm{mg} / \mathrm{L})$ & & & & \\
\hline
\end{tabular}

*Permen LH RI No. 5 Tahun 2014 untuk Limbah Domestik

Berdasarkan Tabel 1 diketahui bahwa proses filtrasi dapat meningkatkan $\mathrm{pH}$ air limbah, dimana filter kombinasi (karbon aktif-pasir-coco fiber-kerikil) jauh lebih efektif dalam meningkatkan $\mathrm{pH}$ yaitu dari 6,1 menjadi 7,8 dengan efektivitas $21,8 \%$. Sedangkan filter coco fiber hanya mampu meningkatkan $\mathrm{pH}$ dari 6,1 menjadi 6,4 dengan efektivitas 4,7\%. Hal ini sesuai dengan hasil penelitian Pinandari et al (2011) yang menyatakan bahwa filter biomassa dari sabut kelapa dapat meningkatkan $\mathrm{pH}$ air limbah yaitu 6 menjadi rata-rata 7,22.

Hasil pengujian alat pengolah limbah cair dengan filter berbahan dasar coco fiber menunjukkan penurunan konsentrasi BOD maupun TSS setelah perlakuan. Berdasarkan Tabel 4.1, efektivitas media filter coco fiber dalam menurunkan konsentrasi BOD adalah $98,58 \%$ dan TSS $83,51 \%$. Penurunan efektivitas terjadi pada sistem kombinasi media filter karbon aktif-pasir-coco fiber-kerikil yaitu BOD 78,33\% dan TSS $81,19 \%$.

Hal ini diduga dipengaruhi oleh penggunaan media filter pasir yang tidak bersih. Pasir diperoleh dari lokasi sekitar penelitian dan dicuci sebanyak $3 x$, namun sangat dimungkinkan jika masih terdapat material-material organik yang menempel pada permukaan pasir sehingga ketika pengujian air limbah, 

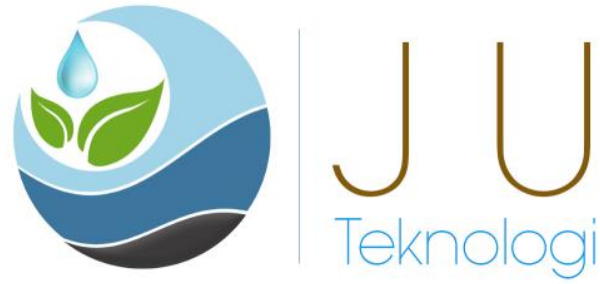

material organik dari pasir ikut terbawa saat proses filtrasi. Selain itu juga dapat dikarenakan distribusi molekul adsorbat yang masuk ke dalam partikel media filtrasi sebagai adsorben tidak diserap secara maksimal dan waktu kontak yang terlalu singkat dengan media filtrasi yaitu 2 jam.

Konsentrasi TSS dan BOD yang mengalami penurunan setelah dilakukan filtrasi dengan media filter berbahan

\section{PENUTUP}

Berdasarkan hasil penelitian, maka dapat disimpulkan bahwa:

1. Kualitas limbah cair rumah makan cepat saji sebelum pengolahan tidak memenuhi baku mutu berdasarkan parameter BOD dan TSS yaitu $1010,73 \mathrm{mg} / \mathrm{L}$ dan 776,00 $\mathrm{mg} / \mathrm{L}$. Setelah melewati pengolahan dengan media filter coco fiber mengalami peningkatan kualitas berdasarkan pengujian terhadap parameter $\mathrm{pH}$ yaitu 6,1 menjadi 6,4 ; BOD turun menjadi $14,36 \mathrm{mg} / \mathrm{L}$ dan TSS turun menjadi $128,00 \mathrm{mg} / \mathrm{L}$. Hal serupa juga terjadi pada media filter kombinasi karbon aktif-pasir-coco fiber-kerikil yaitu pH 6,1 menjadi 7,8; BOD turun menjadi $218,99 \mathrm{mg} / \mathrm{L}$ dan TSS turun menjadi 146,00 mg/L.

\section{DAFTAR PUSTAKA}

Andiese, V. W. (2011). Pengolahan Limbah Cair Rumah Tangga dengan Metode Kolam. Infrastruktur, 1(2), 103-110.

Diharjo, K. (2006). Pengaruh Perlakuan Alkali terhadap Sifat Tarik Bahan Komposit Serat Rami-
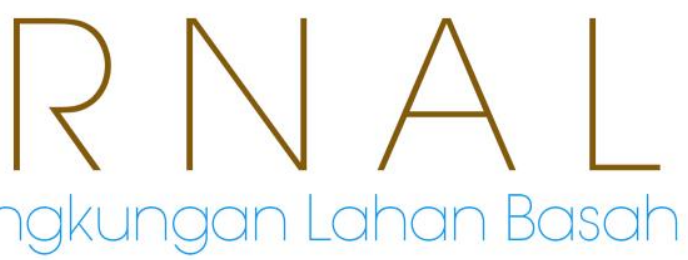

dasar coco fiber dikarenakan filter biomassa coco fiber memiliki komponen penjerat yang aktif menyerap TSS yaitu lignin dan tanin. Bahkan menurut penelitian Silalahi (2007) dan Pinandari et al (2011), kandungan lignin dan selulosa pada tanaman seperti kelapa mampu menjerat logam berat (Pinandari, Fitriana, Nugraha, \& Suhartono, 2011) (Silalahi, Siallagan, \& Monica, 2007)

2. Perlakuan perendaman dengan air dalam pengolahan sabut kelapa menjadi coco fiber tidak mempengaruhi morfologi fisik dan kimia dari coco fiber.

3. Media filter coco fiber memiliki efektivitas dalam meningkatkan kualitas limbah cair rumah makan cepat saji berdasarkan parameter $\mathrm{pH}$, BOD dan TSS yaitu 4,7\%, 98,58\% dan $83,51 \%$. Media filter kombinasi karbon aktif-pasir-coco fiber-kerikil memiliki efektivitas berdasarkan parameter $\mathrm{pH}$, BOD dan TSS yaitu $21,8 \%, 78,33 \%$ dan $81,19 \%$.

\section{UCAPAN TERIMA KASIH}

Terima kasih disampaikan kepada Fakultas Teknik UNTAN yang telah mendanai penelitian ini.

Polyester. Jurnal Teknik Mesin, 8(1), 8-13.

Filliazati, M., Apriani, I., \& Zahara, T. A. (2013). Pengolahan Limbah Cair Domestik dengan BiofilterAerob Menggunakan Media Bioball dan Tanaman 

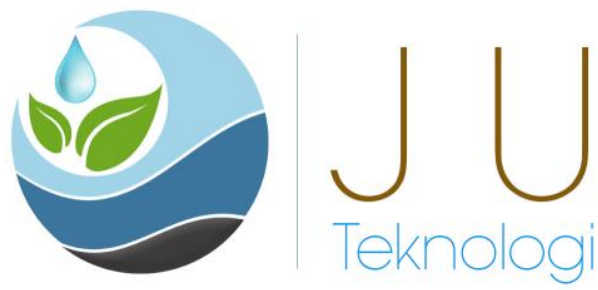

Kiambang. Pontianak: Program Studi Teknik Lingkungan.

Isadiartuti, D., \& Sari, R. (2005). Studi

Efektifitas sediaan Gel

Antiseptik Tangan yang

Mengandung Etanol dan

Triklosan. Majalah Farmasi

Airlangga (Airlangga Journal of

Pharmacy), 5(3).

Joseph, K., Thomas, S., \& Pavithran, C. (1995). Effect of Ageing on the Physical and Mechanical Properties of Sisal-FiberReinforced Polyethylene Composites. Composites Science and Technology, 53(1), 99-110. doi:10.1016/02663538(94)00074-3

Kusnaedi. (2010). Mengolah Air Kotor Untuk Air Minum. Jakarta: Penebar Swadaya.

Niemann. (1998). Principle of Instrumental Analysis. New York, USA.

Sumarni. (2012). Adsorpsi Zat Warna dan Zat Padat Tersuspensi dalam Limbah Cair Batik. Prosiding Seminar Nasional Aplikasi Sains\&Teknologi (SNAST) Periode III. Yogyakarta.
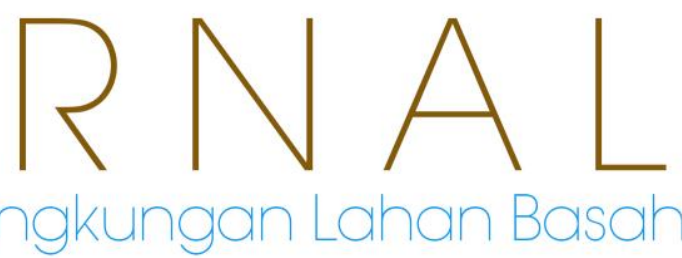

Pinandari, A. W., Fitriana, D. N., Nugraha, A., \& Suhartono, E. 2011). Uji Efektifitas dan Efisiensi Filter Biomassa Menggunakan Sabut Kelapa (Cocos nucifera) sebagai Bioremoval untuk Menurunkan Kadar Logam $(\mathrm{Cd}, \mathrm{Fe}, \mathrm{Cu})$, Total Padatan tersuspensi (TSS) dan Meningkatkan $\mathrm{pH}$ pada Limbah Air Asam Tambang Batubara. Prestasi, 1(1).

Sihombing, J. B. (2007). Penggunaan Media Filtran Dalam Upaya Mengurangi Beban Cemaran Limbah Cair Industri Kecil Tapioka. Bogor: Central Library of Bogor Agricultural University.

Silalahi, M. D., Siallagan, C., \& Monica, E. (2007). Penyisihan Mn2+ dalam Air Sumur dengan Memanfaatkan Sabut Kelapa. Jurnal Teknologi Lingkungan, 4(2), 44-49.

Zahra, L. Z., \& Purwanti, I. F. (2015). Pengolahan Limbah Rumah Makan dengan Proses Biofilter Aerobik. Jurnal Teknik ITS, 4(1), D-35-D-39. 